\title{
Relationship Between the Relational Coordination Model and Quality in the UTEQ
}

\author{
Cristina Checa Morales ${ }^{1}$, Carmen De Pablos-Heredero ${ }^{2 *}$, Yenny Torres ${ }^{3}$, Eduardo Díaz $^{3}$ and Cecilio Barba Capote $^{1}$ \\ ${ }^{1}$ Agricultural Economy Group, Córdoba University, Spain
}

${ }^{2}$ ESIC Business \& Marketing School and Rey Juan Carlos University, Spain

${ }^{3}$ Business Administration, UTEQ University, Spain

*Corresponding author: Carmen De Pablos Heredero, ESIC Business \& Marketing School and Rey Juan Carlos University, Madrid, Spain

\begin{abstract}
The objective of this study was to build an organizational typology that explains the relationship between relational coordination (RC) and satisfaction in higher education. 4,000 cases were analysed in diverse socioeconomic contexts. 19 RC variables were measured. By applying factor analysis, 6 factors have been obtained that explained a $66.23 \%$ of variance. The first three factors were more relevant and are linked to coordination with administration, representative`s cooperation and lectures' cooperation. Discriminant analysis results showed a strong relationship between RC and quality. Quality exhibited high discriminating power in the model (71.64\%), which used 6 factors of RC. The cluster analysis assigned high quality to group 3, associated to high levels of coordination with administration and representatives' coordination. It evidences that an improvement of RC allows reaching best results in terms of quality in higher education
\end{abstract}

Keywords: Relational coordination; satisfaction; higher education; shared objectives; mutual respect; communication; quality

\section{Introduction}

La Coordinación Relacional (CR) es un proceso comunicativo que busca la integración de tareas a través de la comunicación efectiva y las relaciones entre los agentes de la organización [1-5]. Entendiendo la Universidad como organización, con la aplicación del modelo se busca una mejora de la calidad en la Educación Superior. Actually, la higher education es un elemento clave en la sociedad. Con mejores profesionales, todas las organizaciones contarán con un capital humano más cualificado, lo que supondrá mejores resultados productivos [6,7]. La comunicación entre los distintos agentes de una organización está estrechamente ligada con el nivel de calidad de los resultados que ésta produce [8,4]. La Universidad Técnica Estatal de Quevedo, localizada en Ecuador, es una universidad centrada en titulaciones acordes a las exigencias de su entorno, tales como Ciencias Agrarias, Ciencias Pecuarias, Empresariales, Ciencias Ambientales o Ciencias de la Ingeniería. It is graded with " $\mathrm{B}$ " category by the CEAACES (Council of Evaluation, Accreditation and Quality Assurance of Upper Education), in a classification from "A" up to "C", in a decreasing scale. El objetivo de este estudio fue construir una tipología basada en factores obtenidos de la observación del modelo de RC en la UTEQ así como conocer la relación entre relational coordination and Quality [5].

\section{Methods}

Se tomó una muestra de 4,000 alumnos de Universidad Técnica Estatal de Quevedo (Ecuador) durante el curso académico 2014 configurada. Se aplicó un cuestionario que recoge las dos dimensiones de CR. A la dimensión de comunicación pertenecen las variables comunicación precisa, comunicación oportuna y comunicación para la resolución de problemas. A la dimensión de relación pertenecen las variables conocimientos compartidos, respeto mutuo y objetivos compartidos. Los perfiles sobre los que se preguntó fueron personal de administración, profesores, compañeros, representación de estudiantes y "yo mismo" [4].

Se realizó un análisis factorial (AF) como una forma de reducir el número de variables y revelar un modelo de CR mediante relaciones entre variables. Para probar la adecuación del tamaño de la muestra se utilizaron las pruebas de Kaiser-Meyer-Olkin (KMO) y Bartlett [2,6]. El coeficiente alfa de Cronbach, que se calculó 
aplicando un análisis de confiabilidad en factores designados, indicó alta consistencia interna $(\alpha=0.92)$ [5]. Posteriormente, se construyó una tipología de modelos organizativos a través de una análisis clúster. Por último. se relacionaron los elementos obtenidos en los análisis previos con la calidad percibida por los estudiantes [8].

\section{Results}

Applying factor analysis (FA), variables were assigned to 6 factors than explained a $66.23 \%$ of variance with an eigenvalue under one (Tables 1 \& 2). Factor 1 represents a $36.13 \%$ of the variance. It's composed by variables of both $\mathrm{RC}$ dimensions. It shows highest values invariables likre accurate communication, fequent communication, solving problem communication and shared knowledge. All of these variables are related with the profile of administrative officers. This factor is called coordination with administration. Second factor explains a $8.58 \%$ of the variance. It contains variables of both RC dimensions, too. Solving problem communication, shared knowledge, mutual respect and shared goals are the variables of thise factor. The prevailing selected profile in the variables was the one representing students 'representatives, and it's called representatives 'coordination. Third factor represents the $7.25 \%$ of the variance. It shows high scores invariables of relartionship dimensión, lie mutual respect and shared goals, all of them related with lectures profile. In this way, this is lectures'cooperation factor. Fourth factor explains a $5.26 \%$ of variability and, it is associated to variables related to solving problem communication and some variables of relationship RC dimension like shared knowledge, mutual respect and shared goals with classmates. Highest scores in this factor are related to the need to proportionate higher levels of solving problem communication and shared knowledge. This factor represents classmates' coordination. The fifth one explains a $4.59 \%$ of the variance. This factor showed high scores in the profiles related to lecturers and classmates in the items of accurate and frequent communication. This factor represents classroom communication. Finally, the sixth factor, with the $4.42 \%$ of the variabce, is related to the individual capacity to solve problems and it is named autonomy.

Table 1: Relational coordination dimensions.

\begin{tabular}{|c|c|}
\hline Code & Variable \\
\hline 8. $\mathrm{ACCU}_{\text {Admin }}$ & Accurate communication with administrative officers \\
\hline 8.ACCU ${ }_{\text {Lect }}$ & Accurate communication with lectures \\
\hline 8.ACCU $\mathrm{Alass}$ & Accurate commnucation with classmates \\
\hline 9.FREQ $\mathrm{Admin}_{\mathrm{A}}$ & Frequent communication with administrative officers \\
\hline 9.FREQ ${ }_{\text {Lect }}$ & Frequent communication with lectures \\
\hline 9.FREQ $\mathrm{Flass}_{\mathrm{N}}$ & Frequent communication with classmates \\
\hline 10.SOLPRO $_{\text {Myself }}$ & Problem solving communication with myself \\
\hline 10.SOLPRO ${ }_{\text {Lect }}$ & Problem solving communication with lectures \\
\hline 10.SOLPRO $_{\text {Repres }}$ & Problem solving communication with student representative \\
\hline 10.SOLPRO $_{\text {Admin }}$ & Problem solving communication with administrative officers \\
\hline 10.SOLPRO $_{\text {Class }}$ & Problem solving communication with classmates \\
\hline 11.SKNOW $_{\text {Lect }}$ & Shared knowledge with lectures \\
\hline 11.SKNOW & Shared knowledge with student representative \\
\hline 11.SKNOW Admin $_{1}$ & Shared knowledge with administrative officers \\
\hline 11.SKNOW ${ }_{\text {Class }}$ & Shared knowledge with classmates \\
\hline 12.RESPE Lect & Mutual respect with lectures \\
\hline 12.RESPE $E_{\text {Repres }}$ & Mutual respect with student representative \\
\hline 12.RESPE ${ }_{\text {Admin }}$ & Mutual respect with administrative officers \\
\hline 12.RESPE $E_{\text {Class }}$ & Mutual respect with classmates \\
\hline 13.SHARGOAL Lect & Shared goals with lectures \\
\hline 13.SHARGOAL $\mathrm{Repres}$ & Shared goals with student representative \\
\hline 13.SHARGOAL ${ }_{\text {Admin }}$ & Shared goals with administrative officers \\
\hline 13.SHARGOAL $\mathrm{Class}_{\mathrm{C}}$ & Shared goals with classmates \\
\hline
\end{tabular}


Table 2: Factor loading matrix of rotated components.

\begin{tabular}{|c|c|c|c|c|c|}
\hline Items & Loading & Eigenvalue & Explained Variance (\%) & $\alpha$ Cronbach & Factor \\
\hline 8. $\mathrm{ACCU}_{\text {Admin }}$ & 0.628 & 8.30 & 36.13 & 0.77 & 1 \\
\hline 9. $\mathrm{FREQ}_{\mathrm{Admin}}$ & 0.732 & & & & \\
\hline 10. SOLPRO $_{\text {Admin }}$ & 0.728 & & & & \\
\hline 11.SKNOW & 0.651 & & & & \\
\hline 10.SOLPRO $_{\text {Repres }}$ & 0.734 & 1.97 & 8.58 & 0.84 & 2 \\
\hline 11. SKNOW $_{\text {Repres }}$ & 0.745 & & & & \\
\hline 12.RESPE $\mathrm{Repres}$ & 0.756 & & & & \\
\hline 13.SHARGOAL $\mathrm{Repres}$ & 0.757 & & & & \\
\hline 12.RESPE ${ }_{\text {Lect }}$ & 0.760 & 1.67 & 7.25 & 0.75 & 3 \\
\hline 13.SHARGOAL Lect $_{\text {L }}$ & 0.701 & & & & \\
\hline $10 . \mathrm{SOLPRO}_{\text {Class }}$ & 0.706 & 1.21 & 5.26 & 0.81 & 4 \\
\hline 11.SKNOW ${ }_{\text {Class }}$ & 0.750 & & & & \\
\hline 12.RESPE $E_{\text {Class }}$ & 0.640 & & & & \\
\hline 13.SHARGOAL ${ }_{\text {class }}$ & 0.640 & & & & \\
\hline 8. $\mathrm{ACCU}_{\text {Lect }}$ & 0.678 & 1.56 & 4.59 & 0.76 & 5 \\
\hline 8. $\mathrm{ACCU}_{\text {Class }}$ & 0.759 & & & & \\
\hline 9.FREQ ${ }_{\text {Lect }}$ & 0.618 & & & & $\mathrm{~s}$ \\
\hline 9.FREQ $\mathrm{Flass}_{\text {}}$ & 0.744 & & & & \\
\hline $10 . \mathrm{SOLPRO}_{\text {Myself }}$ & 0.623 & 1.02 & 4.42 & - & 6 \\
\hline
\end{tabular}

Table 3: Centroids for each cluster.

\begin{tabular}{|c|c|c|c|c|c|}
\hline Variable & Factor & Cluster 1 & Cluster 2 & Cluster 3 & p-value \\
\hline Coordination with administration & 1 & 1.259 & -4.023 & 6.231 & 0.0000 \\
\hline Representatives' coordination & 2 & 1.282 & -4.120 & 6.405 & 0.0000 \\
\hline Lectures' cooperation & 3 & 1.240 & -3.761 & 5.633 & 0.0000 \\
\hline Classmates' coordination & 4 & 1.127 & -3.532 & 5.405 & 0.0000 \\
\hline Classroom communication & 5 & 0.942 & -2.834 & 4.221 & 0.0000 \\
\hline Autonomy & 6 & 0.357 & -1.160 & 1.814 & 0.0000 \\
\hline
\end{tabular}

Note: a,b,c,d Within row, averages with different superscript differ significantly according to indicated value $\mathrm{p}$.

Cluster analysis which presented the most significant results, was the solution of four groups with Ward's method, based on the Euclidean distances (Figure 1). Table 3 shows the main characteristics of each organisational type. Cluster 1 comprised 46.57\% de los casos. Estre grupo muestra valores intermedios en práticamente todos los factores. Destaca levemente un valor más bajo correspondiente al factor autonomy (factor 6), aunque no supone una gran diferencia con el resto de factores. Cluster 2 comprende el $38.18 \%$ de los casos. Es el grupo que present valores negativos encodes los factories. Predominant los factories coordination with administration and representatives' coordination. Los valores medias se Encuentros end lectures' cooperation, classmates' coordination, classroom communication. El valor más alto dentro de Este grupo avarice end el factor autonomy. Cluster 3 comprende el $15.25 \%$ de los casos. Aunque es el grupo de manor tamanu, present los valores más altos. Desta can las atlas punctuations en coordination with administration and representatives' coordination. Medium values are found in lectures' cooperation, classmates' coordination, classroom communication and to a lesser extent to student's autonomy.

Table 4 shows the general results of the canonical discriminant analysis with all the variables measured [1,7]. In this case, discrimination power was evident because the F statistics of the Wilks' lambda were significant for the discriminant variables. The 
Model classifies $71.64 \%$ of the cases correctly. Figure 2 shows the distribution of cases with respect to factors 1 and 2 . The higher values of quality correspond to high scores of both factors. Table 5 shows the results of the canonical discriminant analysis for each factor. Wilkes' Lambda indica el alto poder discriminante de la calidad referido a cada factor de forma individual. Coeficientes foro canonical variables muestran una alta relación entre la mayor parte de los factores, destacando coordination with administration and representatives' coordination. On the otear hand, los factores classmates' coordination and autónomo shows valores más bajos, indicando una menor relación con la calidad. Mahala Nobis distances indicant la relation existents entre los dos gropes de collided observations (low and high), mestranol una distances de 1.278 entre ambos, con un p-value $<0.0001$.

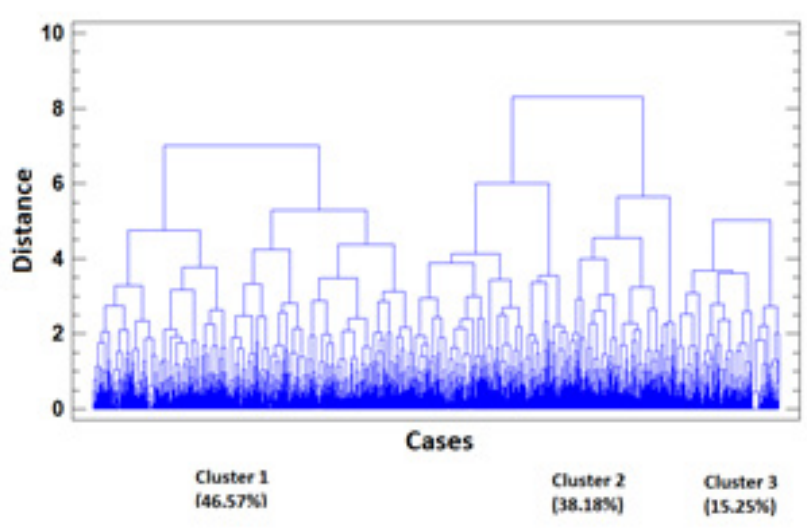

Figure 1: Relational coordination clusters.

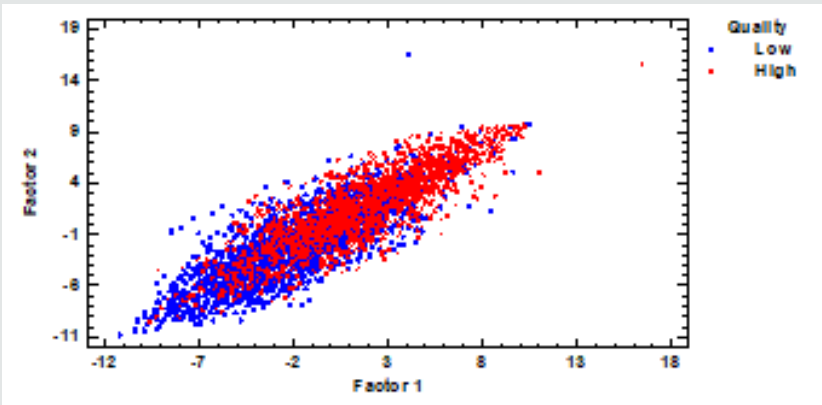

Figure 2: Representation of cases according first and second factors and quality level.

Table 4: Results of the canonical discriminant analysis.

\begin{tabular}{|c|c|c|c|c|c|}
\hline Mosdel & Wilks'Lambda & F & p-value & Correct $^{\text {a }}$ & CAN \\
\hline All factors & 0.757 & 25.75 & $<0.0001$ & $71.64 \%$ & 0.492 \\
\hline
\end{tabular}

Note: aPercent correctly classified into farms assignment (R2=1-tolerance); (-) Non-significant values for this canonical component.
Table 5: Results of the canonical discriminant analysis for each factor.

\begin{tabular}{|c|c|c|c|c|c|}
\hline Factor & Wilks' Lambda & $\mathbf{F}$ & $\mathbf{p}$-value & $\mathbf{R}^{2}$ & $\mathbf{C A N}$ \\
\hline 1 & 0.765 & 36.65 & $<0.0001$ & 0.796 & 0.435 \\
\hline 2 & 0.763 & 25.75 & $<0.0001$ & 0.869 & 0.456 \\
\hline 3 & 0.762 & 22.63 & $<0.0001$ & 0.856 & 0.408 \\
\hline 4 & 0.766 & 40.41 & $<0.0001$ & 0.836 & -0.508 \\
\hline 5 & 0.767 & 48.74 & $<0.0001$ & 0.696 & 0.410 \\
\hline 6 & 0.763 & 28.51 & $<0.0001$ & 0.502 & -0.246 \\
\hline
\end{tabular}

Note: ${ }^{a}$ Percent correctly classified into farms assignment (R2=1-tolerance); (-) Non-significant values for this canonical component.

\section{Discussion}

El análisis factorial muestra 6 factores extraidos de las variables del modelo de RC. Los factores con mayor incidencia en el modelo son coordination with administration representatives' coordination and lectures' cooperation, que suponen más del $50 \%$ de la varianza. Los dos primeros factores son los asociados a una mayor calidad de la universidad. El sexto factor, autonomy, se asocia con peores niveles de calidad. De la tipología se extraen tres modelos organizativos. El primer modelo, de mayor tamaño muestra una presencia general de todos los factores organizativos. De este modo, se observa una calidad media generalizada en la universidad. El segundo modelo, de tamaño intermedio, muestra valores negativos en todos los factores. Destacan como más bajos los factores coordination with administration and representatives' coordination. Según se observa en el análisis discriminante, estos dos factores están asociados a mayores niveles de calidad en la universidad. Por otra parte, el valor más alto de este grupo se encuentra en el sexto factor, autonomy, que está asociado a niveles más bajos de calidad. De este modo, este grupo representa el sector con menor calidad en la universidad. En el tercer modelo, el más pequeño, el factor autonomy presenta una baja puntuación, mientras que los factores con más peso son coordination with administration and representatives' coordination. Por lo tanto, este grupo está asociado a niveles altos de calidad universitaria.

\section{Conclusion}

Existe una relación directa entre calidad y el modelo de RC, de este modo se verifica este modelo para la UTEQ. Según este estudio, la calidad de la universidad se encuentra en un punto medio. Muestra valores balanceados en sus elementos, aunque la autonomía de los estudiantes y la actividad comunicativa de los alumnos en clase son bajas. Para conseguir un mayor nivel de calidad se propone centrar la atención en elementos que mejoren la comunicación con el personal de administración y con la respresentatives'students. Una mejora de las TICs podrá suponer una comunicación más fluida entre esos perfiles y el alumno. 


\section{References}

1. De Pablos Heredero C, Fernández Renedo C, Medina Merodio A (2015) Technical Efficiency and Organ Transplant Performance: a mixed method approach. Int J Environ Res Public Health 12(5): 4869-4888.

2. Garmendia ML (2007) Análisis factorial: una aplicación en el cuestionario de salud general de Goldberg, versión de 12 preguntas. Revista Chilena de Salud Pública 11(2): 57-65.

3. Gittell J, Logan C, Cronenwett J, Foster T, Freeman R, et al. (2018) Impact of relational coordination on staff and patient outcomes in outpatient surgical clinics. Health Care Manage Rev. 44(4).

4. Margalina VM (2014) Success factors in online education: analysis from the Relational Coordination model. PHd diss, University Rey Juan Carlos, Spain.

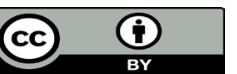

This work is licensed under Creative Commons Attribution 4.0 License

To Submit Your Article Click Here:

Submit Article
5. Mendez D, Macía F (2007) Análisis factorial confirmatorio de la escala de actitudes hacia la estadística. Cuadernos de Neuropsicología 1(3): 174371.

6. Özen Y (2017) The development of will perception salce and practica in a psycho education program with its validity and reliability. Educational Research and Reviews 9(21): 1125-1132.

7. Simanaviciene Z, Giziene V, Jasinskas E, Simanavicius A (2015) Assessment Of Investment In Higher Education: State Approach. Procedida Social and Behavioral Sciences 191: 336- 341.

8. Toro Mujica P, Aguilar C, Vera R, García A (2015) Sheep production system in the semi arid zone: Changes and simulated bio-economic performances in case study in Central Chile. Livestock Science 180: 209219.

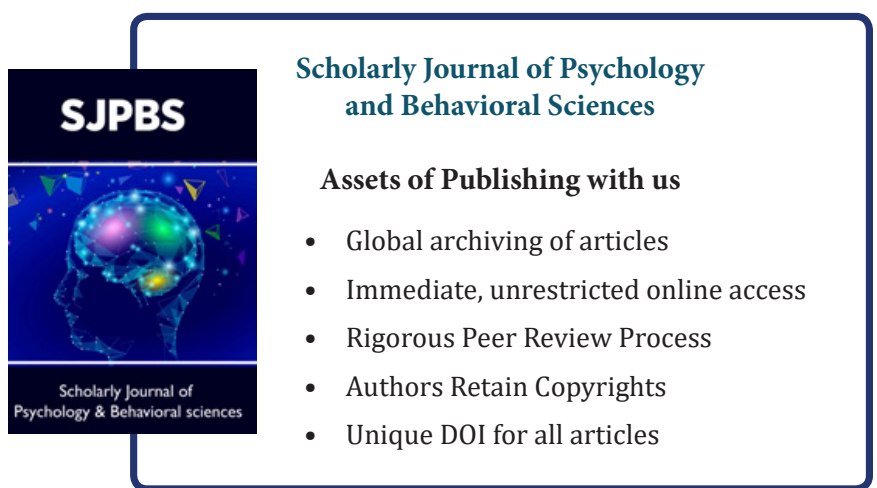

